ORIGINAL ARTICLE

\title{
Age as the Risk Factor that Affected the Increased Degree of Uterine Prolapse
}

\author{
Shervil Kagayaita Sayko ${ }^{1}$, Eighty Mardiyan Kurniawati ${ }^{2}$, Pudji Lestari ${ }^{3 *}$
}

${ }^{1}$ Midwifery Education Program, Faculty of Medicine, Universitas Airlangga, Surabaya, Indonesia

${ }^{2}$ Departement of Obstetrics and Gynecology, Faculty of Medicine, Universitas Airlangga Surabaya, Indonesia

${ }^{3}$ Departement of Public Health and Preventive Medicine, Faculty of Medicine, Universitas Airlangga Surabaya, Indonesia

\section{A R T I C L E I N F O}

\section{Article history:}

Received 28 April 2018

Received in revised form 17 Mei

2018

Accepted 17 May 2018

Available online 30 April 2018

\section{Keywords:}

Knee osteoarthritis,

Age,

Gender,

Kellgren-Lawrnce scoring system,

Knee osteoarthritis severity index.

*) Corresponding author: pules30@yahoo.com

\begin{abstract}
A B S T RA C T
Introductions: Uterine prolapse is a gynecological problem that women often experience with a prevalence of $50 \%$ and is predicted that the next 30 years will increase by $45 \%$ as life expectancy increases. The uterine prolapse is influenced by several mutually supportive factors. The purpose of this study was to analyze the relationship between these factors to the degree of uterine prolapse.

Methods: This research was a cross sectional study. The number of samples were 65 patients with uterine prolapse at Policlinic Gynecology RSUD Dr. Soetomo Surabaya from 2015-2017. To find out the significant level, the collected data will be tested with Fisher Exact Test statistic at significance level $\alpha=0,05$.

Results: From total 65 patents, most cases was 4 th degree uterine prolapse from 27 cases $(41,5 \%)$. Trend of uterine prolapse events occurs at age $\geq 50$ years and parity $\geq 4$. There was significant difference between degree of uterine prolapse with age factor $(p=0,016)$ and obesity $(\mathrm{p}=0,041)$. There was no significant difference between the parity factor and the degree of uterine prolapse $(\mathrm{p}=0.508)$.

Conclusion: Age is a major factor affecting the degree of uterine prolapse, weakening of pelvic floor tissue and muscle in elderly women is the main cause.
\end{abstract}

\section{Introduction}

The uterine prolapse is a form of pelvic organ prolapse (POP) characterized by a descent of the uterus into the vagina caused by the weakness of the endopelvic ligaments, especially the transverse ligaments. $(1,2)$

POP is one of the most common indications of gynecological surgery.(3) The Women's Health Initiative (WHI) study states that the incidence of POP in the United States is $41 \%$ of women aged 50-79 and uterine prolapse ranks third (14\% of patients with POP).(4) The incidence of uterine prolapse in Indonesia remains uncertain. Genesis of uterine prolapse at Policlinic Gynecology RSUD Dr. Soetomo from 2007 - 2011 is quite high and is the most POP case that is 66,30\%.(5) POP incidence, including uterine prolapse, is very high in women and it has been predicted that over the next 30 years the demand for management will increase by $45 \%$ as the life expectancy increases.(6) Because gynecologic abnormalities are common in women and their management requires costs are high, then understanding of POP especially uterine prolapse becomes important(7)

The risk factor for uterine prolapse is very diverse and mutually supportive of one another. Several studies

Biomolecular and Health Science Journal 
have shown that age, parity, obesity and menopausal status are risk factors that play a role in increasing the incidence and severity of uterine prolapse. $(8,9)$

The occurrence of uterine prolapse does not lead to mortality or severe morbidity. However, the incidence of uterine prolapse is very influential on the life of women both social, psychological and physical. Problems or physical disorders that occur in patients with prolapse can reduce women's reproductive health, such as $44.57 \%$ of women feel uncomfortable because there is mass in and out of the genitals..(5) In another study stated that uterine prolapse is also very influential in the sexual life for example decrease in orgasm, desire, lubrication and lead to decreased satisfaction and quality of sexual intercourse.(6) Whereas according to Shrestha et al, the disorders caused by uterine prolapse include defecation problem by $71 \%$ and the feeling of heat when urinate by $59 \%$. This certainly decreases the quality of life of a woman.(10)

There are many government efforts that have been made in the prevention of risk factors that increase the incidence of uterine prolapse. This is done in order to improve the quality of human life in Indonesia, which has been scheduled in 5th point of Nawa Cita. One of the programs is Healthy Indonesia Program (Program Indonesia Sehat) (11) Program Indonesia Sehat itself is implemented by enforcing the three main pillars, one of which is: the application of a healthy paradigm. The implementation of healthy paradigm is done with mainstreaming health strategy in development, strengthening of promotive and preventive effort, and community empowerment.(12)

Several studies have examined the association of various risk factors for uterine prolapse. $(8,9,13,14)$ but no studies have examined the association of these factors with the degree of uterine prolapse. Based on the background above, the researcher wanted to examine the factors that influence the degree of uterine prolapse patients in Policlinic Gynecology RSUD Dr. Soetomo Surabaya.

\section{Methods}

This research was an observational cross sectional analytic study. The independent variables were age, parity, and obesity, while the dependent variable was the degree of uterine prolapse. Population was outpatient medical record data at Policlinic Gynecology RSUD Dr. Soetomo Surabaya in the period January 2015 December 2017 with a diagnosis of uterine prolapse and has received approval of ethical clearance from ethics commission of Faculty of Medicine Universitas Airlangga and RSUD Dr. Soetomo Surabaya. Samples were obtained using Consecutive sampling technique from reachable population of research according to inclusion criteria including patient who go to Polyclinic Gynecology RSUD Dr. Soetomo Surabaya in January 2015 - December 2017 with a diagnosis of uterine prolapse and complete medical records (including data on identity, anamnesis factors affecting uterine prolapse, physical examination, diagnosis and uterine prolapse regimens). The exclusion criteria include uterine prolapse patients with other additional diagnoses that may aggravate and make a diagnosis of uterine prolapse bias, such as cervical carcinoma; tumor and/or malignant disorders of the uterus, adnexa, connective tissue and pelvic cavity; congenital (uterine), adnexa, vaginal and external genital abnormalities; history of chronic constipation; history of chronic lung disease; history of surgery and radiation history. In addition, patients with degree uterine prolapse increased or moved within the sampling period also included in the exclusion criteria.

Analysis conducted in this research includes univariate and bivariate analysis. Univariate analysis is performed to see the characteristics or description and frequency distribution of each of the variables studied. Data of this category will be presented with the size of the presentation or proportion. Bivariate analysis was conducted to determine the effect of age, parity and oberity factor on the degree of uterine prolapse in Policlinic of Gynecology of RSUD Dr. Soetomo Surabaya. Bivariate analysis was done by using Fisher Exact Test using SPSS program. (SPSS.Inc., Chicago, IL) through Fisher Exact Test with $\alpha=0,05$, if $p<0,05$ then there is relationship and if $p>0,05$ there is no relationship. The closeness of the relationship between independent and dependent variables is expressed in contingency coefficient.

\section{Results}

The population in this study amounted to 121 patients with uterine prolapse. Then medical record search was conducted and found that there were only 65 complete medical records and meet the criteria of inclusion and exclusion. Thus, the research sample in this study was 65. (Table 1) Of the 65 cases of uterine prolapse it can be seen that most cases of uterine prolapse in Polyclynic of Gynecology of RSUD Dr.Soetomo from 2015-2017 is a 4th degree uterine prolapse from 27 cases $(41,5 \%)$ so that the management conducted mostly is the operation action that is 32 cases $(49,2 \%)$. Trend of uterine prolapse events occurs at age $\geq 50$ years and parity $\geq 4$. The trend for the majority BMI is normal.

Table 1 Characteristics and Actions on Patients with Uterine Prolapse in Polyclinic Gynecology RSUD Dr. Soetomo Surabaya Year 2015-2017

\begin{tabular}{lc}
\hline & $\mathbf{n = 6 5}$ \\
\hline Degree of Uterine Prolapse & \\
1 degree of uterine prolapse & $8(12.3 \%)$ \\
2 degree of uterine prolapse & $15(23.1 \%)$ \\
3 degree of uterine prolapse & $15(23.1 \%)$ \\
4 degree of uterine prolapse & $27(41.5 \%)$ \\
Procedures & \\
Operation & $32(49.2 \%)$ \\
Pessarium & $22(33.8 \%)$ \\
Others & $11(16.9 \%)$
\end{tabular}




\begin{tabular}{lc} 
Age & \\
Age $\geq 50$ & $59(90,8 \%)$ \\
Age $<50$ & $6(9,2 \%)$ \\
Parity & \\
Parity $\geq 4$ & $40(61,5 \%)$ \\
Parity $<4$ & $25(47,5 \%)$ \\
BMI & $3(4,6 \%)$ \\
Underweight & $33(50,8 \%)$ \\
Normal & $26(40,0 \%)$ \\
Overweight & $3(4,6 \%)$ \\
Obese & \\
\hline
\end{tabular}

The variables that had significant differences with the increase of uterine prolapse degree were the age variable $(\mathrm{p}=0.016)$ and the BMI variable $(\mathrm{p}=0.0373)$ because the significance was smaller than 0.05 ( $\mathrm{p}<0.05)$. While for parity variable there is no significant difference with increasing degree of uterine prolapse because the significance or $\mathrm{p}$ value is greater than 0,05 ( $p>0,05)$. The strength of the relationship between the degree of uterine prolapse and the age variables (coefficient contingency $=0.372$ ) and obesity (coefficient contingency $=0.373$ ) indicates that there is a strong relationship between the two (Table 2).

\section{Discussion}

The number of uterine prolapse cases showed that cases of uterine prolapse increase with the increase in the life expectancy of a woman. This is influenced by various factors that are related to each other, thus increasing the case of the uterine prolapse itself. Uterine prolapse occurance tends to occur in elderly women $(\geq$ 50 years), because at this age there is a lot of decline in function in the female body, especially reproductive function. This decrease in reproductive function affects pelvic floor muscle strength, resulting in increased uterine prolapse events..(15) As for women aged <50 years the incidence of uterine prolapse may be triggered by several other factors, since the prolapse of uteri is a multifactorial disease.

Trend or tendency of uterine prolapse events occurs in mothers with high parity. High parity is associated with the delivery. Multi parity leads to progressive labor Table 2 Relationship between Factors on Uric Prolapse Degrees in Polyclinic of Gynecology RSUD Dr. Soetomo Surabaya Year 20152017

\begin{tabular}{|c|c|c|c|c|c|c|c|}
\hline \multirow{2}{*}{ Factors } & \multicolumn{4}{|c|}{ Uterine Prolapse } & \multirow[b]{2}{*}{$\mathrm{n}$} & \multirow[b]{2}{*}{$\mathrm{p}$} & \multirow{2}{*}{$\begin{array}{c}\text { Conti } \\
\text { Ngency } \\
\text { Coef. }\end{array}$} \\
\hline & $1^{\text {st }}$ Degree & $2^{\text {nd }}$ Degree & $3^{\text {rd }}$ Degree & $4^{\text {th }}$ Degree & & & \\
\hline \multicolumn{8}{|l|}{ Age } \\
\hline Age $\geq 50$ & $5(8.9 \%)$ & $13(22.0 \%)$ & $15(25.4 \%)$ & $26(44.0 \%)$ & 59 & \multirow{2}{*}{0,016} & \multirow{2}{*}{0,372} \\
\hline Age $<50$ & $3(50.0 \%)$ & $2(33.3 \%)$ & $0(0.0 \%)$ & $1(16.6 \%)$ & 6 & & \\
\hline \multicolumn{8}{|l|}{ Parity } \\
\hline Parity $\geq 4$ & $5(12.5 \%)$ & $7(17.5 \%)$ & $9(22.5 \%)$ & $19(47.5 \%)$ & 40 & \multirow{2}{*}{0,508} & \multirow{2}{*}{-} \\
\hline Parity $<4$ & $3(12.0 \%)$ & $8(32.0 \%)$ & $6(24.0 \%)$ & $8(32.0 \%)$ & 25 & & \\
\hline \multicolumn{8}{|l|}{ BMI } \\
\hline Obesity & $0(0.00 \%)$ & $0(0.00 \%)$ & $3(100 \%)$ & $0(0.00 \%)$ & 3 & \multirow{2}{*}{0,041} & \multirow{2}{*}{0,373} \\
\hline Not Obese & $8(12.90 \%)$ & $15(24.19 \%)$ & $12(19.36 \%)$ & $27(43.55 \%)$ & 62 & & \\
\hline
\end{tabular}

injury in the endopelvic fascia and muscle laceration, especially the levator ani muscles..(8) Delivery can affect the uterine prolapse such as not standardize delivery, doing kristeler, leads meneran before the complete opening and third stage management which is not done well.

Trend that occurs in patients with uterine prolapse is not obese. Although many theories suggest that obesity has an effect on increasing the incidence of uterine prolapse, in this case the occurrence of uterine prolapse may occur due to other weight factors. Given that the previous studies were conducted on type A (level 3 fasces).

Actions taken on uterine prolapse patients are based on the type, severity of symptoms, age, general state of the patient, sexual functional requirements, fertility, as well as risk factors for recurrence. The purpose of this operative action is generally to improve vaginal anatomy, repair or maintenance of bladder function, repair or maintenance of bowel function and repair or maintenance of sexual function..(1) The largest uterine prolapse found in this study is uterine grade IV prolapse, so the majority of its management is surgery.

The results of Fisher Exact Test showed that there was a significant correlation between degree of uterine prolapse and age factor and had a strong relation between the two. This is consistent with the theory that increasing age makes the fascia tissue more rigid and easy to rupture. The fascia of the pelvic floor will also weaken with age, so that the pelvic floor tissue can not retain the organs contained in it..(15)

In addition, at the age of more than 40 years until before menopause begin, estrogen levels are decreasing. Estrogen serves to stimulate the skin to increase the synthesis of hydroxyproline and proline as a collagen network. Reduced collagen tissue causes weakness in the pelvic floor muscles that usually occur 5-10 years after menopause.(16) 
In Dr. Kariadi General Hospital (RSUD Dr. Kariadi) Semarang, $97.6 \%$ of grade III and IV grade III uterine prolapse occur in women over 50.(8) This means that aging and menopause also play a role in increasing the degree of uterine prolapse. It is also supported by a study that suggests that age has an influence on increasing POP levels, including uterine prolapse $(\mathrm{p}<0.001)$. (9)

According to researchers, age is a major factor affecting the degree of uterine prolapse. The decline in sexual function and reproduction in older women certainly has a major impact on the health of women themselves, one of which weakening the tissues and pelvic floor muscles in charge of supporting the uterus to remain in place. The older the age, the more severe weakness of the basal tissue and muscles of the pelvis, so the the degree of uterine prolapse suffered by the patient will be higher.

Fisher Exact Test result showed that there is no significant relationship of parity factor with the degree of uterine prolapse. This is inconsistent with the theory that multiparity will result in progressive labor injury in the endopelvic fascia and muscle lacerations, especially the levator ani muscles, which can lead to uterine prolapse. $(8,17)$

In Dr. Kariadi Semarang $97.6 \%$ of grade III and IV grade uterine prolapse occur in multipara women. So parity also plays a role in increasing the degree of uterine prolapse. Similarly, according to Kim et al. study which states that parity $\geq 3$ has an influence on increasing POP levels, including uterine prolapse $(\mathrm{p}=0.005)$.(9)

Indeed the patients of uterine prolapse in RSUD Dr. Soetomo Surabaya in 2011-2017 had the majority of parity $\geq 4$ accounted to $61.5 \%$. However, judging from the degree of uterine prolapse there is no significant difference between uterine prolapse of degree $1,2,3$ or 4. This is why parity has no relationship to the degree of uterine prolapse. Although parity has no significant difference to the degree of uterine prolapse, the trends indicate that parity results in increased incidence of uterine prolapse itself.

This can happen because parity is also affected by several factors such as: previous labor type, labor with action, age at first delivery, birth weight of the previous child and also abnormalities during labor (such as shoulder dystocia or prolonged stage 2).(18) In another study stated that there is a small proportion of uterine prolapse cases occurring in nullipara, a rarity which should be studied further.(19)

Although the results of Fisher Exact Test analysis of obesity factors showed that there was a significant difference in the incidence of uterine prolapse rate between obese and non-obese patients. However, there is no evidence that obesity affects the degree of uterine prolapse. This is because the trend or the tendency of uterine prolapse patients with obese were only $4.6 \%$.

This is incompatible with the theory that uterine prolapse will tend to increase with increasing intraabdominal pressure.(20) Increased intra-abdominal pressure provides excessive burden on the pelvic floor muscles, resulting in weakness of the pelvic floor muscles. In the Women's Health Initiative (WHI) study it was stated that women with $25-30 \mathrm{~kg} / \mathrm{m} 2$ BMI increased the risk of uterine prolapse by $31-39 \%$, whereas women with BMI> $30 \mathrm{~kg} / \mathrm{m} 2$ the risk increased by $40-75 \% 8$. Other studies suggest that there is a relationship between obese women and POP incidence, including uterine prolapse $(\mathrm{p}=0.004) .(21)$

However, this is consistent with Kim et al. study, which states that there is no association between BMI and POP degrees (including uterine prolapse)..(9) Other studies also suggest no association between obesity and POP degrees, including uterine prolapse, but obesity may affect pelvic floor disturbance symptoms such as urinary incontinence and urinary incontinence..(22) Other studies also suggest that there is no significant association between POP, including uterine prolapse, to the occurrence of uterine prolapse based on POP-Q score.(23)

This fact shows that there are other weight factors that influence the degree of uterine prolapse in RSUD Dr. Soetomo. Given that RSUD Dr. Soetomo is a tertiary health care, in which the patients referred here must have a weight factor that cannot be handled in the secondary health care. Thus, obesity is not the only factor that triggers an increase in the degree of uterine prolapse.

\section{Conclusion}

Uterine prolapse is a multifactorial disease. But with age, there is a decrease in organ function, one of which is the ligament and pelvic floor muscles that can no longer support the contents of the pelvis. So it can increase the degree of uterine prolapse. It can be concluded that age is the most influential factor to increase the degree of uterine prolapse, without ignoring other factors that can aggravate the condition.

\section{Conflict of Interest}

The author stated there is no conflict of interest

\section{References}

1. Prasetyo AT, al e. Kapita Selekta Uroginekologi. Yogyakarta: Bagian Obstetri Ginekologi FK UGM; 2011.

2. Prawirohardjo S. Ilmu Kandungan. Jakarta: PT. Bina Pustaka Sarwono Prawirohardjo; 2010.

3. Zaki A, Kurniawati EM, Mustokoweni S. Peningkatan Ketebalan Serat Elastin Dinding Vagina pada Prolapsus Organ Pelvis Anterior. Majalah Obstetri \& Ginekologi. 2016;24(1):31-6.

4. Yoga K, Pratiwi M, Putra IGM. Pelvic Organ Prolapes. E-Jurnal Medika Udayana. 2013;2(4):709-36. 
5. Nizomy IR, Prabowo RP, Hardianto G. Correlation between Risk Faktors and Pelvic Organ Prolapse in Gynecology Outpatient Clinic, Dr. Soetomo Hospital Surabaya 2007-2011. Majalah Obstetri \& Ginekologi. 2013;21(2):61-6.

6. Kuhn A, Bapst D, Stadlmayr W, Vits K, Mueller MD. Sexual and organ function in patients with symptomatic prolapse: are pessaries helpful? Fertility and sterility. 2009;91(5):1914-8.

7. Richter H, Varney R. Pelvic Organ Prolapse. California: Berek and Novak's Gynecology; 2007.

8. Hardianti BC, Pramono BA. Faktor-faktor yang Berhubungan dengan Kejadian Prolapsus Uteri di RSUP Dr. Kariadi Semarang. Medika Media Muda. 2015;4(4):498-508

9. Kim CM, Jeon MJ, Chung DJ, Kim SK, Kim JW, Bai SW. Risk Factor for Pelvic Organ Prolapse. International Journal of Gynecology and Obstetrics. 2007;98(1):248-51.

10. Shrestha B, Onta S, Choulagai B, Poudya A, Pahari DP, Uprety A, et al. Women's Experinces and Health Care-seeking Practice in Relation to Uterine Prolapse in a Hill District of Nepal. BMC Women's Health. 2014;14(20):1-9.

11. RI P. No. 39 Tahun 2016 tentang Pedoman Penyelenggaraan Program Indonesia Sehat Dengan Pendekatan Keluarga. Jakarta: Kementerian Kesehatan, 2016.

12. Kemenkes-RI. Pedoman Umum Program Indonesia Sehat dengan Pendekatan Keluarga. Jakarta: Kementerian Kesehatan 2016.

13. Silitonga IR, Sukarsa MRA, Pohan LR, Armawan E, Handono B. Perbandingan Kerapatan Kolagen Ligamentum Sakrouterina pada Pasien dengan dan tanpa Prolaps Uteri. MKB. 2015;47(4):212-7.
14. Cessaria DE, Manoe IM, Molejono ER. Elastin Expression is the Strongest Risk Factor for Developing Pelvic Organ Prolapse. Indones J Obstet Gynecol. 2013;1(4):204-8.

15. Edmonds D. Dewhurst's Textbook of Obstetrics \& Gynaecology. UK: Wiley-Blackwell;; 2012.

16. Konar H. Textbook Of Gynecology. New Delhi: Jaypee Brothers Medical Publisher; 2013.

17. Smith R. Netter's Obstetrics \& Gynecology. USA: Saunders Elsevier; 2008.

18. Karatayli R, Gezginc K, Kantarci AH, Acar A. Successful treatment of uterine prolapse by abdominal hysteropexy performed during cesarean section. Archives of gynecology and obstetrics. 2013;287(2):319-22

19. Kim JO, Jang SA, Lee JY, Yun NR, Lee SH, Hwang SO. Uterine prolapse in a primigravid woman. Obstetrics \& gynecology science. 2016;59(3):241-4

20. Callahan T, Caughey A. Blueprints Obstetrics \& Gynecology. China: Lippincott Williams \& Wilkins; 2013.

21. Whitcomb EL, Lukacz ES, Lawrence JM, Nager CW, Luber KM. Prevalence and degree of bother from pelvic floor disorders in obese women. International urogynecology journal and pelvic floor dysfunction. 2009;20(3):289-94.

22. Washington BB. The association between obesity and stage II or greater prolapse. American journal of obstetrics and gynecology. 2010;201:1-4.

23. Ermawati, Syafrianto, Bachtiar H. Hubungan antara Usia, Paritas, Pekerjaan dan Indeks Massa Tubuh dengan Kejadian Prolaps Organ Panggul Berdasarkan Skor Pelvic Organ Prolapse Quantification. Obgin Emas. 2014;3(17):29-34. 